ZatącZnils

DOI 10.21697/zk.2020.7.27

\title{
HITCHCOCK WOBEC HOLOCAUSTU (MEMORY OF THE CAMPS)*
}

KATARZYNA TARAS
Wydział Operatorski i Realizacji Telewizyjnej PWSFTviT w Łodzi Direction of Photography and Television Production Department, The Polish National Film Television and Theatre School in Łódź kasiataras@gmail.com

ORCID: 0000-0003-1500-5595

Sidney Bernstein, producent i przedsiębiorca filmowy, wiosną 1945 roku zaprosił Alfreda Hitchcocka, by ten jako „supervising director” czy też „treatment advisor” wspomógł twórców w nadaniu ostatecznego kształtu filmowi dokumentalnemu, na który składały się materiały zrealizowane przez amerykańskich, brytyjskich i radzieckich operatorów frontowych tuż po wyzwoleniu obozów koncentracyjnych. „Hitch” propozycję przyjął i postanowił pomóc za darmo'. Interesujące jest, jak artysta zareagował na to doświadczenie. Według wspomnień operatora z filmowego oddziału brytyjskiej armii „mistrz suspensu” po zapoznaniu się z materiałem zarejestrowanym w czasie wyzwolenia obozu koncentracyjnego Bergen-Belsen przez tydzień trzymał się z daleka od Pinewood Studios ${ }^{2}$. Z kolei André

* Za inspirację, by zająć się tym filmem, dziękuję Jolancie Dylewskiej, która natrafiła na niego podczas swojej kwerendy w połowie lat 90. w Imperial War Museum. Jak pisze Patrice Taddonio, film ten zwykło się też nazywać „Alfred Hitchcock lost Holocaust film"; zob. P. Taddonio, Hitchcock and the Holocaust: Memory of the Camps, www.pbs.org/wgbh/frontline/article/hitchcock-and-the-holocaust-memory-of-the-camps [dostęp 31.05.2020].

1 P. Taddonio, op. cit.

2 R. Brody, Hitchcock and the Holocaust, 5.01.2014, „The New Yorker”, https:// www.newyorker.com/culture/richard-brody/hitchcock-and-the-holocaust [dostęp 31.05.2020]. 
Singer, reżyser Night Will Fall ${ }^{3}$, dokumentu zrealizowanego z inicjatywy HBO, którego Memory of the Camps stało się integralną częścią, wyznał, że choć Hitchcocka uprzedzono o tym, co zobaczy, jego szok był tak wielki, że po wojnie rzadko wspominał o tym filmie ${ }^{4}$.

Realizację Memory of the Camps, czyli tak naprawdę German Concentration Camps Factual Survey, bo taki tytuł miał nosić film Bernsteina, rozpoczęto pod koniec kwietnia 1945 roku, jednak produkcję (mimo zgromadzenia przez producenta prawdziwego dreamteamu realizatorów, pośród których, oprócz Hitchcocka ${ }^{5}$, byli: Richard Crossman i Colin Willis - autorzy scenariusza, a także montażyści - Stewart McAllister, Peter Tanner i Marcel Cohen) porzucono już we wrześniu. Film, a ściślej to, co z niego zostało, czyli sześć aktów ${ }^{6}$, pierwszy raz szerszej publiczności zaprezentowano dopiero

3 Night Will Fall powstał z inicjatywy producentki Sally Angel, która pracowała kiedyś w Imperial War Museum i wiedziała o prowadzonej rekonstrukcji dokumentu pochodzącego z 1945 roku. Sally Angel zaprosiła do projektu André Singera. Singer doskonale zrekonstruował intencje Sidneya Bernsteina, który pojechał do Bergen-Belsen jako wysłannik brytyjskiego rządu (konkretnie: Ministerstwa Informacji), by zobaczyć panujące tam warunki, a po tym, co zastał, zapragnął zrobić film o zbrodniach, jakich dopuścili się Niemcy „w imieniu Trzeciej Rzeszy”, i zarejestrować dowody, które przydałyby się podczas procesów zbrodniarzy (zob. S. King, HBO's „Night Will Fall” chronicles making of WWII Holocaust film, 25.01.2015, „Los Angeles Times”, www.latimes.com/entertainment/tv/la-et-st-hbonight-will-fall-alfred-hitchcock-20150126-story.html [dostęp 31.05.2020]). Night Will Fall, którego telewizyjna premiera odbyła się w Międzynarodowy Dzień Pamięci Ofiar Holocaustu w 2015 roku, jest utworem absolutnie autonomicznym, choć - co nie może dziwić - złożonym z materiałów nakręconych 70 lat wcześniej; można go również traktować jako szczególnego rodzaju „making of” dotyczący German Concentration Camps Factual Survey. Rolę narratorki powierzono Helenie Bonham Carter, w filmie znalazły się też wypowiedzi wyzwalanych, wyzwalających, a także filmujących wyzwalanie. W lipcu 2014 roku Night Will Fall pokazano na Jerusalem Film Festival razem z dodatkowymi materiałami pochodzącymi z roku 1945.

${ }^{4}$ S. King, op. cit.

5 Hitchcock zrealizował w 1944 roku trzy filmy propagandowe: The Fighting Generation, Malgaska przygodę oraz Bon Voyage.

6 Wersja godzinna jest dostępna na stronie IsraelCNN, https://israelcnn.com/video/ holocaust/221871525 [dostęp 31.05.2020]. I to tam widziałam ten film po raz pierwszy. 
w 1984 roku podczas festiwalu filmowego w Berlinie, z kolei w 1985 roku, już jako Memory of the Camps - jedną z części cyklu Frontline, pokazała sieć $\mathrm{PBS}^{7}$. Premiera pełnej, pracowicie zrekonstruowanej przez fachowców z Imperial War Museum ${ }^{8}$ i trwającej 75 minut wersji filmu odbyła się w 2014 roku podczas festiwalu filmowego w Berlinie.

Podstawowym celem Sidneya Bernsteina było, po pierwsze, utrwalenie dowodów zbrodni, bowiem producent wierzył w nieuchronność procesów, jakim zostaną poddani hitlerowscy zbrodniarze 9 . Po drugie, planował realizację filmu dla niemieckiej widowni - obraz powstawał na wyraźne polecenie Psychological Warfare Division, odpowiedzialnej za polityczną aktywność Brytyjczyków w Niemczech. Materiały, którym Hitchcock miał nadać ostateczny szlif, by stworzyć przekonujący i wiarygodny przekaz, były efektem działań ekip amerykańskich, brytyjskich oraz radzieckich. To one dokumentowały dowody zbrodni. Na Memory of the Camps składaja się obrazy wzbogacone komentarzem napisanym przez Crossmana i czytanym „Z offu” przez Trevora Howarda; momentami zdjęciom towarzyszą wypowiedzi tych, których sfilmowano - najczęściej ofiar, choć kilka razy głos oddano oprawcom. Co może się wydać interesujące polskiemu widzowi, w części z Bergen-Belsen słyszymy skargę Polki: „Kto mi zapłaci za te młode lata?”. Zdjęcia w przeważającej części nie są inscenizowane, ze szczególnego rodzaju inscenizacją mamy do czynienia tylko w scenach przenoszenia ciał więźniów do masowych mogił, bo filmowcy (albo - co o wiele bardziej prawdopodobne - po prostu żołnierze, którzy obozy koncentracyjne wyzwolili) zmusili oprawców do pochowania swoich ofiar. Oczywiście sceny, które obserwujemy, nie mają nic wspólnego z pełnym szacunku pochówkiem, obrazują raczej ciągnięcie ludzkich szczątków i wrzucanie ich do zbiorowych mogił. Dawni kaci robią to wszystko bez rękawiczek i maseczek - wydaje

7 Zob. German Concentration Camps Factual Survey [hasło], Wikipedia, https://en.wikipedia.org/wiki/German_Concentration_Camps_Factual_Survey [dostęp 31.05.2020] oraz P. Taddonio, op. cit.

8 Prace rozpoczęto w grudniu 2008 roku.

$9 \mathrm{Nb}$. materiały zrealizowane na potrzeby filmy Bernsteina pomogły w osądzeniu dwóch oprawców z Bergen-Belsen: Fritza Kleina, którego zdekonspirowała wypowiedź przed kamerą, oraz komendanta obozu, Josefa Kramera. 
się, że wreszcie muszą namacalnie poczuć fizyczność tych, których nie uważali przecież za ludzi.

Memory of the Camps inicjuje wiosenny pejzaż i informacja o dotarciu aliantów do miasteczka Bergen. Po chwili „bukoliczny nastrój ujęcia”, jak pisze Stuart Jeffries ${ }^{10}$, burzy informacja o tym, co poczuli wyzwoliciele. A mianowicie - pewien szczególny zapach: rozkładających się ciał, ale również odór ludzi gnijących jeszcze za życia z wyniszczenia, głodu, brudu i chorób. Kwietniową aurę brutalnie zakłóciła woń śmierci.
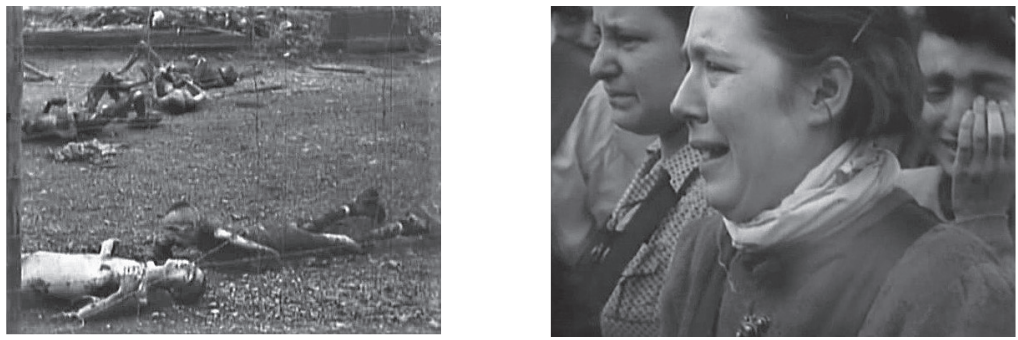

Il. 1 i 2. Kadry z filmu Memory of the Camps

Już od pierwszego ujęcia czytelna jest motywacja Bernsteina, który chce pokazać, że fabrykę śmierci umiejscowiono tuż obok zwykłego miasteczka. Twórca nie wierzy, że nie można było nie wiedzieć o tym, co działo się w dawnym Stalagu 311 (XI C), pod gołym niebem (w takich warunkach przetrzymywano radzieckich jeńców, których „dokwaterowano” tu w lipcu 1941 roku - jak możemy się domyśleć, niewielu z nich przetrwało zimę) oraz w barakach. Zresztą twórcy (może nawet nieco przekornie) tłumaczą powody takiej „nieświadomości” - na początku filmu otrzymujemy krótkie wprowadzenie w najnowszą (wtedy) historię Niemiec (zob. kolaż obrazów z kluczowych momentów Trzeciej Rzeszy). Można domniemywać, że działania propagandowe Goebbelsa przyniosły skutek, ale nie da się przecież wszystkiego wytłumaczyć najdoskonalszą nawet propagandą. Choć z drugiej strony wiadomo, jak Trzecia Rzesza karała swoich niepokornych obywateli.

${ }_{10}$ S. Jeffries, The Holocaust film that was too shocking to show, 9.01.2015, „The Guardian”, www.theguardian.com/film/2015/jan/09/holocaust-film-too-shocking-to-show-night-will-fall-alfred-hitchcock [dostęp 31.05.2020]. 
Łatwo oceniać czyjeś postępowanie, strach, brak reakcji na systemowe bestialstwo, nieangażowanie się, kiedy nie jest się zmuszonym wybierać między życiem czyimś a własnym lub swoich bliskich.

Można by rzec, iż dalej w filmie jest już standardowo, ale widok umarłych czy też cierpiących trudno tak określić. Widzimy stosy martwych ciał, tak wychudzonych, że ledwo przypominających ludzkie zwłoki. Widzimy tych, którzy ocaleli mimo wygłodzenia, chorób, ran, przeprowadzanych na nich eksperymentów medycznych. Widzimy dzieci o pustych oczach, których pierwsze lata albo nawet dni życia upłynęły w piekle ${ }^{11}$. Wreszcie obserwujemy próby przywracania normalności na terenie obozu Bergen-Belsen: doprowadzanie wody, wydawanie posiłków, leczenie, odwszawianie - co w mych oczach wygląda dość irytująco, bo w przywrócenie przejawów normalnego życia na tak unurzanym w śmierci terenie ja, mieszkanka Europy Wschodniej, pochodząca z państwa, którego znaczną część mieszkańców poddano eksterminacji, nie wierzę. I to jest chyba też ten moment, kiedy Bernstein wyszedł z roli świadka i stał się alianckim propagandzistą, ale to jedyny zarzut, jaki można sformułować wobec tego filmu, zwłaszcza kiedy porówna się go z Nazi Concentration Camps George’a Stevensa (1945) ${ }^{12}$.

Obraz Stevensa - reżysera, producenta, ale również autora zdjęć, podwójnego laureata Oscara za Miejsce pod słońcem (A Place in the Sun,1952) i Olbrzyma (Giant, 1956) - poraża, i to nawet współczesnego widza (a może właśnie współczesnego widza?), epatując obrazami martwych, okaleczonych, chorych ciał więźniów obozów koncentracyjnych. Stevens nie zawahał się pokazać ani niedopalonych resztek pozostawionych w piecu krematoryjnym, ani nagich pośladków schorowanego więźnia, który jest tak chudy, że trudno rozpoznać, czy to mężczyzna, czy kobieta. W jego filmie mamy też do czynienia z rekonstrukcją sposobów dręczenia więźniów. Dzisiaj,

11 I filmu Memory of the Camps nie będę kojarzyć z masowymi mogiłami, widokiem komór gazowych, ale właśnie z tymi dziećmi, w szczególności z dwójką niespełna chyba dwuletnich maluchów, wychudzonych, choć już siedzących w czystej pościeli. Matek, czy też matki, nigdzie nie widać. Te maluchy mają oczy, które już wszystko widziały.

12 Producentem tego filmy był John Ford. Jeśli chodzi o aktywność filmową podczas wojny, to Stevens zrealizował jeszcze That Justice be Done (1945), The Nazi Plan (1945) oraz George Stevens' World War II Footage (1946). 
w 2020 roku, obrazy z Bergen-Belsen, Dachau, Ravensbrück, Buchenwaldu, Mauthausen, Ludwigslust, Ohrdruf, Gardelegen, Auschwitz nie dziwią, choć nadal przerażają. Zwłaszcza nam, mieszkańcom Europy Wschodniej, jakby „wtopiły się w krwioobieg”, ale wtedy, w 1945 roku, naprawdę mogły wydać się niewiarygodne. I właśnie aby temu zapobiec, zatrudniono Hitchcocka. Ponoć pracował nad tym filmem miesiąc ${ }^{13}$, pomógł przy montażu piątego i szóstego aktu, czyli materiałów z Dachau i Buchenwaldu ${ }^{14}$. Warto zwrócić uwagę na odmienne podejście filmowców do kwestii przemocy i okrucieństwa: Bernstein jakby uznał, że mało kto uwierzy, iż to, czego świadectwa zastał w obozach koncentracyjnych, wydarzyło się naprawdę; Stevens postanowił zaatakować tym, co tam zastał.

Nie do ustalenia jest, na czym dokładnie polegał wkład Hitchcocka w film Bernsteina, to znaczy, które ujęcia Hitchcock odrzucił, a jakie zostawił. Wiadomo tylko, że zależało mu na uwiarygodnieniu tych nieprawdopodobnych i niemieszczących się w głowach czy to zwykłych Niemców, czy też ludzi z państw, gdzie nie było obozów koncentracyjnych. Ci pierwsi najprawdopodobniej je wypierali, ci drudzy - nie chcieli w nie wierzyć. Jego celem było również pokazanie, jak blisko normalnego życia realizowano „ostateczne rozwiązanie”. I chyba właśnie w tym zaakcentowaniu bliskości śmierci i życia, a ściślej: w pokazaniu śmierci atakującej w cieniu spokojnego życia, w unaocznieniu faktu, że horror dział się tuż obok, po drugiej stronie ulicy - jedni umierali, podczas gdy inni uprawiali ogródki (do czego przecież Führer namawiał) - objawia się „Hitch”, który gdy uświadomił sobie, że nie ma do czynienia z fikcją, tylko z jak najbardziej realną dokumentacją jak najbardziej realnych zbrodni, przestał mieć ochotę na skończenie filmu ${ }^{15}$. To wydaje mi się szczególnie ważne, kiedy przypomnimy sobie, jak „mistrz suspensu” traktował w swoich dziełach przemoc. Okazuje się, że - jako reżysera - interesowała go jedynie przemoc wykreowana, dziejąca się li tylko w świecie stworzonym przez niego i funkcjonującym zgodnie z wymyślonymi przez niego regułami.

13 Zob. German Concentration Camps Factual Survey [hasło], op. cit.

${ }_{14}$ R. Brody, op. cit.

15 Wiem to od Jolanty Dylewskiej, której z kolei taką informację przekazała archiwistka w podeszłym wieku z Imperial War Museum. 

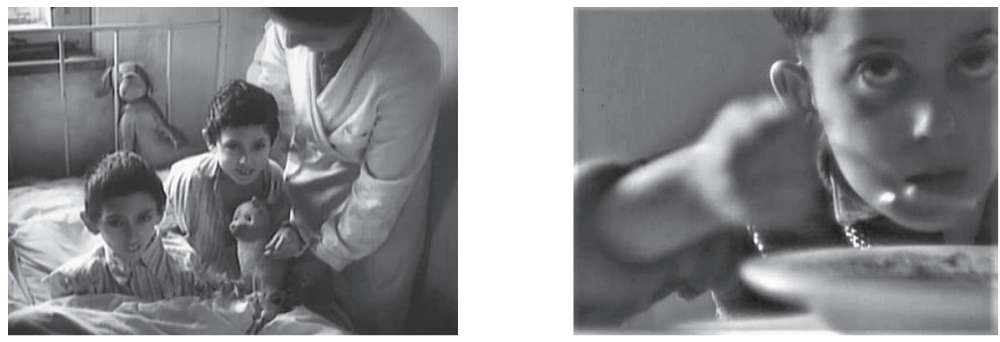

\section{Il. 3 i 4. Kadry z filmu Memory of the Camps}

Hitchcock uznał zatem, że środkiem umożliwiającym uwiarygodnienie wojennych okropności jest pokazanie tych, którzy byli tuż obok i wiedli normalne życie. By przekonać odbiorcę o autentyczności przedstawionych obrazów, zaproponował pokazanie zebranych w Auschwitz włosów, obrączek, okularów i szczoteczek do zębów. Wyeksponowanie konkretu zdawało się chronić aliantów przed zarzutami o fałszowanie historii. Odradzał używanie trików technicznych, jakichkolwiek ozdobników, opowiadał się natomiast za korzystaniem $\mathrm{z}$ ujęć zrealizowanych w nieco szerszych planach - pokazujących kontekst, otoczenie; czasami optował za wstawieniem nieco dłuższego ujęcia lub panoramy ${ }^{16}$. Zdaniem Richarda Brody’ego umieszczenie w filmie establishingów, czyli ujęć ustanawiających, również miało na celu uwiarygodnienie obrazów śmierci, zapobieżenie oskarżeniom o fałszowanie rzeczywistości ${ }^{17}$.

Kwestią równie interesującą jak to, czy można rozpoznać „Hitcha” w tym wskazaniu bliskości śmierci i życia, a ściślej: śmierci dziejącej się w cieniu życia, jest więc przebijająca przez wszystkie komentarze i wspomnienia dbałość Bernsteina i Hitchcocka o uwiarygodnienie obrazów zarejestrowanych w obozach. Dlaczego tak im na tym zależało? Czy chodziło o to, że w taki ogrom przemocy, której skutki zarejestrowały kamery operatorów wojskowych, żaden widz w latach 40. by nie uwierzył? Czy raczej - że w ogóle trudno uwierzyć w to, że ludzie ludziom uczynili coś takiego? ${ }^{18}$ No bo jak

16 Zob. German Concentration Camps Factual Survey [hasło], op. cit.

${ }_{17}$ R. Brody, op. cit.

18 Jak najbardziej świadomie dokonałam trawestacji motta Medalionów Zofii Nałkowskiej, gdzie czytamy: „Ludzie ludziom zgotowali ten los”. Z kolei 
można było spodziewać się zaprojektowania, a potem wybudowania „fabryk śmierci"? Fakt, że my dziś w to wierzymy, wiemy o tym, jesteśmy tego pewni, dowodzi przede wszystkim naszego wyedukowania historycznego. Być może jednak jest też w tym jakiś element zobojętnienia współczesnych na przemoc, przejaw utraty niewinności (o czym pisał już Adorno, uznający, że po Oświęcimiu „pisanie wierszy jest barbarzyństwem”, a wszelka kultura śmietniskiem ${ }^{19}$ )?

Co wynika z udziału Hitchcocka w Memory of the Camps? Po pierwsze, jest to dowód, za jakiego fachowca uchodził, skoro, bądź co bądź, mistrza kreacji poproszono o wsparcie w uwiarygodnieniu niewiarygodnych dla ówczesnych widzów obrazów. Po drugie, jego reakcja - tygodniowa nieobecność w Pinewood Studio spowodowana tym, co zobaczył - zdaje się dowodzić wrażliwości „mistrza suspensu” na przemoc, która rozegrała się w rzeczywistości; jest argumentem przemawiającym za tym, że traktowanie przemocy jako środka artystycznego niewiele ma wspólnego z wyrażaniem na nią przyzwolenia w świecie realnym.

A dlaczego przerwano prace nad Memory of the Camps i film od razu, w 1945 roku, powędrował na półkę? André Singer tłumaczy to najpierw dość wykrętnie („co było dobrym pomysłem w maju, w czerwcu i lipcu 1945 roku - już niekoniecznie"20), po czym już konkretnie wyjaśnia, że przestraszono się, iż obywatele Niemiec stracą zaufanie do aliantów, co mogło skomplikować odbudowę ich kraju, o czym już przecież zaczęto myśleć. Ponadto brytyjscy decydenci zorientowali się, że drastyczny obraz wzmoże sympatię dla żydowskich uchodźców, którzy byli jeszcze w obozach na terenie Europy i pragnęli jechać do swojego państwa, o stworzeniu którego coraz częściej i głośniej wspominano, a przecież Wielka Brytania miała wystarczająco dużo problemów z rodzącym się syjonizmem. Podobnie tę kwestię widzi Branko Lustig, w przyszłości jeden z producentów Listy Schindlera Stevena Spielberga, który jako dziecko był więźniem BergenBelsen, choć wyraża się nieco ostrzej, mówiąc wprost o problemach, jakie

w Dziennikach czasu wojny pod datą 28 lipca 1944 roku pisarka zapisała: „Ludzie ludziom gotują ten los".

19 T.W. Adorno, Dialektyka negatywna, tłum. K. Krzemieniowa, współpraca S. Krzemień-Ojak, Warszawa 1986, s. 515.

20 S. King, op. cit. 
Brytyjczycy mieli z Żydami. Lustig ma tu na myśli obawy, że nie tyle Memory of the Camps mógł wzbudzić sympatię dla ofiar, ile zaostrzyć nastroje syjonistów ${ }^{21}$. Są to jedynie domniemania, ponieważ - jak zauważył Singer jedynym dokumentem wyjaśniającym powody zatrzymania obrazu jest notka z Foreign Office, że „prezentacja tak okrutnego filmu nie byłaby dobrym pomysłem"22.

I tak oto Hitchcock przegrał z prawami ekonomii i polityką wielkiego mocarstwa.

\section{Bibliografia}

Theodor W. Adorno, Dialektyka negatywna, tłum. K. Krzemieniowa, współpraca S. Krzemień-Ojak, PWN, Warszawa 1986.

Richard Brody, Hitchcock and the Holocaust 9.01.2014, „The New Yorker”, https:// www.newyorker.com/culture/richard-brody/hitchcock-and-the-holocaust. Stuart Jeffries, The Holocaust film that was too shocking to show, 9.01.2015, „The Guardian” www.theguardian.com/film/2015/jan/09/holocaust-film -too-shocking-to-show-night-will-fall-alfred-hitchcock.

Susan King, HBO's „Night Will Fall” chronicles making of WWII Holocaust film, 25.01.2015, „Los Angeles Times”, www.latimes.com/entertainment/tv/la-et-st-hbo-night-will-fall-alfred-hitchcock-20150126-story.html.

Patrice Taddonio, Hitchcock and the Holocaust: Memory of the Camps, 2.02.2015, Frontline, www.pbs.org/wgbh/frontline/article/hitchcock-and -the-holocaust-memory-of-the-camps/.

\section{Hitchcock against the Holocaust (Memory of the Camps)}

This sketch is a kind of commentary (gloss) to a little-known episode in Alfred Hitchcock's work, which was the director's collaboration on Memory of the Camps (the film producer Sidney Bernstein invited Hitchcock in the spring of 1945 to assist the filmmakers in giving the final shape to the documentary film made by American, British and Soviet frontline operators just after the liberation of several concentration camps). The author of the article poses questions about the contribution of the 'master of suspense' to this

${ }^{21}$ Zob. German Concentration Camps Factual Survey [hasło], op. cit.

22 Ibidem. 
shocking, unfinished documentary, expressing the opinion that as a creator he was only interested in violence created in the space of fiction, in a world functioning according to the rules he invented.

Keywords: Alfred Hitchcock, Sidney Bernstein, Holocaust, documentary film 